\title{
Distribusi dan Pemetaan Varian-varian Bahasa Bugis di Pulau Lombok
}

\author{
Desi Rachmawati ${ }^{*}$
}

\begin{abstract}
Abstrak
Bahasa yang digunakan oleh suatu komunitas merupakan refleksi dari totalitas kebudayaan masyarakat komunitas tersebut. Selanjutnya pemetaan bahasa sangat penting karena peta bahasa yang dihasilkan dapat digunakan sebagai alat untuk memonitor program pegembangan bahasa Indonesia sebagai bahasa nasional dan program pelestarian bahasa-bahasa daerah. Penentuan dialek-dialek atau subdialek bahasa Bugis pun dilakukan dengan menggunakan metode dialektometri yang penekanannya pada persebaran geografis dan jumlah varian serta jumlah penutur bahasa Bugis yang terdapat di Pulau Lombok. Bahasa Bugis di Pulau Lombok dapat dikelompokkan ke dalam dua dialek, yaitu dialek Bugis Haji Lombok Kruak (DBHLK) dan dialek Bugis Pelangan (DBP).
\end{abstract}

Kata kunci: varian-varian bahasa, dialektometri, dan kantong bahasa (enklave)

\section{Pengantar}

Dilihat dari hubungan antara bahasa dan budaya, kiranya perlu dilakukan pemetaan terhadap bahasa-bahasa daerah yang ada di Indonesia karena dengan terekamnya perbedaan-perbedaan atau kesamaan bahasa antara komunitas yang satu dengan komunitas yang lain.

Sehubungan dengan hal di atas, Lauder (1990:1) menjelaskan bahwa pemetaan bahasa sangat penting karena peta bahasa yang dihasilkan dapat digunakan sebagai alat untuk memonitor program pengembangan bahasa Indonesia sebagai bahasa nasional dan program pelestarian bahasa-bahasa daerah dilain pihak. Sebuah peta bahasa

\footnotetext{
*) Sarjana Pendidikan, Pembantu Pimpinan pada Kantor Bahasa Prov. NTB
} 
idealnya harus dapat merekam aktivitas berbahasa di daerah tempat bahasa itu berasal dan juga di luar daerah tempat terdapatnya komunitas tutur bahasa tersebut. Penelitian terhadap komunitas tutur bahasa di luar daerah tempat bahasa itu berasal atau daerah kantong bahasa perlu dilakukan karena penelitian tersebut dapat menginformasikan adanya komunitas suatu suku bangsa dan distribusi suatu bahasa di suatu wilayah. Selain itu, penelitian ini juga dapat menginformasikan tingkat mobilitas suku bangsa-suku bangsa di Indonesia berdasarkan banyaknya komunitas suku bangsa tesebut di luar daerah asalnya. Penelitian ini juga dapat menginformasikan derajat adaptasi sosial suatu suku bangsa berdasarkan pada derajat adaptasi linguistiknya (Mahsun, 2005).

Bahasa Bugis sebagai salah satu bahasa komunitas pendatang yang ada di Nusa Tenggara Barat sampai saat ini masih menempati fungsinya sebagai alat komunikasi dalam tata kehidupan rumah tangga dan antaranggota masyarakat pemakainya. Dengan demikian, sudah selayaknya bahasa daerah di Indonesia pada umumnya dan bahasa Bugis pada khususnya mendapat perhatian dari para ahli bahasa karena bahasa daerah ini menentukan kelangsungan kebudayan nasional di Indonesia.

Selanjutnya, bahasa daerah tersebut yang memiliki penutur yang cukup besar dan saling mempertahankan keberadaannya dan tidak menutup kemungkinan akan terjadi saling mempengaruhi antara satu sama lainnya. Oleh karena itu, masalah ini sangat menarik untuk diteliti terutama yang berkaitan dengan pemetaan, jumlah penutur dan muculnya variasi lingual yang terdapat pada tiap-tiap bahasa. Variasi-variasi lingual itu akan memunculkan perbedaan bahasa bersangkutan secara geografis dengan bahasa asalnya. 
Mengingat penelitian ini merupakan kajian variasi dialektal, maka teori yang digunakan adalah teori dialektologi, dalam hal ini teori dialektologi diakronis (periksa Mahsun, 1995). Menurut teori ini, bahwa perbedaan dialektal/subdialektal terjadi karena perkembangan historis yang dialami oleh suatu bahasa. Sebagai ilustrasi, pengucapan bunyi *[b] Proto-Austronesia (PAN) sebagai bunyi $[\mathrm{w}]$ pada penutur bahasa Jawa (BJ) misalnya, tidaklah terjadi karena adanya keinginan yang menggebugebu dari para penutur bahasa tersebut untuk bangun pagi-pagi secara serentak mengucapkan PAN *[b] sebagai BJ [w], melainkan ada beberapa penutur yang dalam jangka waktu tertentu mengucapkan $*[b]$ sebagai [w], lalu kecenderungan itu menyebar pada penutur-penutur lainnya. Hal ini mengisyaratkan bahwa setiap kajian dialektal/subdialektal yang didasarkan pada pertimbangan perbedaan sinkronis haruslah mempertimbangkan secara serius tentang mekanisme perubahan diakronis. Artinya, untuk memperoleh gambaran yang jelas tentang perbedaan dialektal/subdialektal dari suatu bahasa perlu dilakukan pengkajian yang bersifat deskriptif (sinkronis) dan historis (diakronis). Dengan kata lain, kajian dialektal akan dapat dilakukan secara tuntas terhadap suatu bahasa jika kajian itu didasarkan pada konsep teori dialektologi diakronis (Mahsun, 1995).

Kajian dialektologi diakronis meliputi dua aspek, yaitu aspek deskriptif dan aspek historis. Dari aspek deskriptif, kajian dialektologi disasarkan pada upaya:

a. pendeskripsian perbedaan unsur-unsur kebahasaan yang terdapat dalam bahasa yang diteliti. Perbedaan itu mencakup bidang fonologi, morfologi, sintaksis, leksikon, dan semantik, termasuk pula perbedaan dari aspek sosiolinguistik;

b. pemetaan unsur-unsur bahasa yang berbeda itu; 
c. penentuan isolek sebagai dialek atau subdialek dengan berpijak pada unsur-unsur kebahasaan yang berbeda yang telah dideskripsikan dan dipetakan;

d. membuat deskripsi yang berkaitan dengan pengenalan dialek dan subdialek melalui pendeskripsian ciri-ciri kebahasaan yang menandai dan/ atau membedakan antara dialek/subdialek yang satu dengan lainnya.

Adapun dari aspek historis, penelitian dialektologi disasarkan pada upaya:

a. penelusuran pengaruh antardialek/subdialek bahasa yang diteliti serta situasi persebaran geografisnya;

b. penelusuran unsur kebahasaan yang merupakan inovasi internal ataupun eksternal dalam dialek-dialek/subdialek-subdialek bahasa yang diteliti, termasuk bahasa sumbernya (untuk inovasi eksternal) serta situasi persebaran geografisnya dalam tiap-tiap dialek atau subdialek itu;

c. penelusuran unsur kebahasaan yang berupa unsur relik pada dialek/ subdialek yang diteliti dengan situasi persebaran geografisnya;

d. penelusuran saling hubungan antarunsur-unsur kebahasaan yang berbeda di antara dialek atau subdialek bahasa yang diteliti;

e. membuat analisis dialek/ subdialek yang inovatif dan konservatif;

f. dalam pengertian yang terbatas membuat rekonstruksi sejarah daerah yang bahasanya diteliti (bandingkan Mahsun, 1995 dengan Nothofer, 1987). Namun, patut ditambahkan bahwa tidak semua aspek historis di atas akan dibahas dalam tulisan ini, tetapi disesuaikan dengan cakupan masalah. Perbedaan yang 
mendasar antara bentuk-bentuk yang dikategorikan sebagai bentuk yang berbeda secara fonologis dengan yang berbeda secara leksikal terletak pada dapat/tidaknya bentuk-bentuk yang berbeda itu dihubungkan pada sebuah bentuk purba yang sama. Apabila bentuk-bentuk yang berbeda itu dapat dihubungkan pada sebuah bentuk bahasa purba yang sama, bentuk-bentuk yang berbeda itu dikategorikan berbeda secara fonologis. Sebaliknya, jika bentuk-bentuk yang berbeda itu tidak dapat dihubungkan pada sebuah bentuk asal yang sama, perbedaan itu terjadi pada level leksikal. Sebagai contoh, pasangan bentuk yang berbeda dalam BS: don $(\mathrm{DJ}) \cong \operatorname{din}(D T) \cong \operatorname{dain}(\mathrm{DTn}) \cong \operatorname{dIn}(\mathrm{DSB})$ 'daun' merupakan pasangan yang perbedaannya dapat dikategorikan sebagai perbedaan pada level fonologis karena dapat dilacak pada asal yang sama, yaitu diturunkan dari bahasa purba yang sama, yaitu PAN/ PBSS * daun 'daun', sedangkan pasangan bentuk yang berbeda dalam bahasa yang sama: ayam (DJ, DT, DSB) manok (DTn) 'ayam' merupakan dua bentuk yang dikategorikan sebagai bentuk yang berbeda pada level leksikal karena masing-masing berasal dari bentuk purba yang berbeda.

Patut ditambahkan bahwa perbedaan pada level fonologi ini mencakup perbedaan yang bersifat teratur atau korespondensi dan perbedaan yang bersifat sporadis (tidak teratur) atau yang disebut variasi. Perbedaan yang bersifat teratur ini disebut sebagai korespondensi sangat sempurna, sempurna, dan kurang sempurna.

Perbedaan itu disebut korespondensi sangat sempurna apabila perbedaan yang disebabkan oleh perubahan bunyi itu terjadi pada semua data yang disyarati oleh kaidah perubahan serta sebaran geografisnya 
sama, sedangkan perbedaan yang berupa korespondensi sempurna juga terjadi pada semua data yang disyarati oleh kaidah perubahan, tetapi sebaran geografis antarcontoh yang satu dengan contoh yang lainnya tidak sama. Adapun perbedaan disebut korespondensi kurang sempurna jika perubahan bunyi itu terjadi pada 2-5 buah contoh dengan sebaran geografisnya sama; dan perbedaan disebut variasi jika kaidah perubahan bunyi itu hanya terjadi pada sebuah atau dua buah contoh dengan sebaran geografis yang berbeda. Perbedaan yang berupa variasi ini dapat berupa, antara lain metatesis, asimilasi, disimilasi, apokope, sinkope, aferesis, kontraksi dll. (bandingkan Mahsun, 1995 dengan Crowley, 1987 dan Lehmann, 1973).

\section{Pembahasan}

Dari keseluruhan data instrumen yang tersedia, telah dianalisis hanya 400 kosakata dasar data yang berisi kosakata dasar swadesh, kosakata budaya dasar bagian tubuh, sistem kekerabatan, gerak dan kerja, dan kata tugas. Sementara data-data lain tidak dianalisis sebab analisis fonologi dan leksikon dianggap representatif menjawab permasalahan yang dirumuskan. Data-data lain yang tidak dianalisis itu akan dijadikan data awal dalam rangka mendukung program pemetaan Bahasa Nasional yang diprogramkan Pusat Bahasa. Hasil analisis akan dipaparkan di bawah ini secara runtut dengan urutan perbedaan fonologi, perbedaan leksikon dan glos-glos yang realisasinya sama.

\subsection{Deskripsi Perbedaan Linguistik Daerah Sebaran}

\subsubsection{Perbedaan Fonologi}

Sebelum dilakukan pendeskripsian perbedaan fonologi, terlebih dahulu akan ditentukan prinsip-prinsip pendekatan yang digunakan. Hal ini dianggap perlu agar tidak terjadi tumpang tindih antara perbedaan 
fonologi dan perbedaan leksikon. Adapun prinsip-prinsip yang dimaksud adalah:

a. Perbedaan yang terdapat pada bentuk (morfem) yang menyatakan makna yang sama itu dianggap sebagai perbedaan fonologi jika perbedaan itu merupakan korespondensi. Artinya, perbedaan itu muncul secara teeratur antara fonem bentuk-bentuk tersebut dan karenanya semua bentuk yang memperlihatkan perbedaan itu berasal dari satu etimon.

b. Apabila di samping perbedaan yang berupa korespondensi itu terdapat refleks etimon lain yang digunakan untuk menyatakan makna tersebut, kondisi semacam ini diperlakukan sebagai perbedaan fonologi dan perbedaan leksikon.

c. Apabila perbedaan di antara bentuk-bentuk yang menyatakan makna yang sama itu berupa variasi dan perbedaan itu hanya terjadi pada satu atau dua bunyi (atau fonem) yang sama urutannya, hal itu akan dianggap sebagai perbedaan fonologi.

d. Perbedaan karena proses metatesis, desimilasi, asimilasi, kontraksi fonem, dan aferesis akan diperlakukan sebagai perbedaan fonologi, dan dikelompokkan ke dalam perbedaan yang berupa variasi.

Dengan demikian, perbedaan fonologi yang dibicarakan di sini dapat dibedakan empat macam, yaitu korespondensi konsonan dan variasi konsonan. Untuk lebih jelas keempat jenis perbedaan fonologi di atas akan dibicarakan satu persatu berikut ini. Namun, perlu ditambahkan bahwa perbedaan fonologi yang dimaksud adalah perbedaan yang menyangkut perbedaan fonetik atau yang merupakan perbedaan fonologikal. Leksem-leksem yang merupakan realisasi dari satu makna, yang terdapat di antara fonologi apabila: (1) perbedaan yang terdapat 
pada leksem-leksem yang menyatakan makna yang sama itu muncul secara teratur atau merupakan korespondensi, dan (2) perbedaan diantara leksem-leksem yang menyatakan makna yang sama itu berupa variasi dan perbedaan itu hanya terjadi pada satu atau dua bunyi yang sama urutannya. Pada prinsipnya, perbedaan yang terdapat pada leksemleksem yang menyatakan makna yang sama itu dianggap sebagai perbedaan fonologi jika leksem-leksem itu diturunkan dari satu etimon prabahasa/proto bahasa yang sama (Mahsun, 1995:24).

\subsubsection{Korespondensi Vokal}

Untuk korespondensi vokal akan dikemukakan salah satu contoh dari sekitar 14 buah perbedaan yang berhasil ditemukan:

1. Korespondensi antara $\mathrm{E}_{\simeq}$ /-k\#, misalnya:

$$
\begin{aligned}
& \text { [tapparEy] [tapparəy] 'danau' } \\
& \text { [iyamanEy] [yamanəy] 'semua', }
\end{aligned}
$$

Daerah sebaran korespondensi vocal ini adalah:

[E] pada daerah pengamatan: 1 dan 2

[ə] paada daerah pengamatan: 3 dan 4

\subsubsection{Korespondensi konsonan}

Korespondensi konsonan akan dikemukakan salah satu contoh dari sekitar 7 buah perbedaan yang berhasil ditemukan:

1. Korespondensi antara $\mathrm{f} \simeq \mathrm{p} / \#-$

[foloyi] [ poloyi] 'potong'

Daerah sebaran korespondensi konsonaan ini adalah:

[f] pada daerah pengamatan : 1,2 dan 4

[p] pada daerah pengamatan: 3

\subsubsection{Variasi vokal}


Perbedaan yang berupa variasi vokal yang ditemukan dalam penelitian ini adalah sekitar 19 buah perbedaan. Berikut akan dikemukaakan salah satu contoh dari perbedaan tersebut.

1. Variasi vokal [ə] [e]/\#k-

[ə] digunakan pada daerah pengamatan 1 dan 2

[e] digunakan pada daerah pengamatan 3 dan 4 contohnya: [dənaq] [denaq] 'tidak'

\subsubsection{Variasi vokal}

Perbedaan yang berupa variasi vokal yang ditemukan dalam penelitian ini adalah sekitar 14 buah perbedaan. Berikut salah satu contoh dari perbedaan tersebut.

1. Variasi konsonan $\mathrm{w} \sim \mathrm{h} / \#-$

[w] digunakan pada daerah pengamatan 1 dan 2

[h] digunakan pada daerah pengamatan 3 dan 4 contohnya: [wae] [Uhae] 'air'

\subsubsection{Leksikon}

Berdasarkan data yang diperoleh dari penelitian ini, ternyata perbedaan linguistik cukup banyak ditemukan dalam bidang leksikon sekitar 38 buah perbedaan. Namun demikian, yang dikemukakan pada bagian berikut hanya salah satu contoh saja dan diharapkan dapat memberikan gambaran daerah sebaran perbedaan-perbedaan tersebut secara menyeluruh. Perlu dikemukakan pula, bahwa semua perbedaan leksikon itu berwujud perbedaan yang berupa variasi. Sehubungan dengan itu, akan dikemukakan beberapa perbedaan leksikon yang dimaksud seperti di bawah ini:

1. Makna 'akar' memunculkan dua varian, yaitu: akay yang digunakan pada daerah pengamatan 1 dan 2; Ure yang digunakan pada daerah pengamatan 3 dan 4 . 


\subsection{Penetuan Isolek sebagai Dialek dan Subdialek}

Dalam bagian ini akan digambarkan mengenai hubungan yang terdapat antara isolek yang digunakan pada setiap daerah pengamatan. Daerah pengamatan yang dimaksud adalah di Desa Labuhan Haji, Kecamatan Labuhan Haji untuk daerah pengamatan 1; Desa Labuhan Lombok, Kecamatan Pringgabaya untuk daerah pengamatan 2; Kecamatan Keruak untuk daerah pengamatan 3; Desa Pelangan, Kecamatan Sekotong Barat untuk daerah pengamatan 4. Daerah pengamatan 1,2 dan 3 itu berada di wilayah Kabupaten Lombok Timur, sedangkan daerah pengamatan 4 terletak di wilayah Kabupaten Lombok Barat. Untuk sampai pada penentuan isolek sebagai dialek itu, upaya yang dilakukan adalah menghitung jumlah isoglos yang menyatukan daerah-daaerah pengamatan di atas yang menampilkan gejala kebahasaan yang serupa. Dengan demikian, jumlah isoglos yang menyatukan daerahdaerah pengamatan yang menampilkan gejala kebahasaan yang serupa itu akan dijadikan landasan dalam menentukan isolek sebagai subdialek atau dialek. 
Oleh karena itu, dengan menggunakan metode dialektometri hasil yang diperoleh yang berupa persentase jarak unsur-unsur kebahasaan di antara empat daerah pengamatan itu adalah sebagai berikut.

\begin{tabular}{|c|c|c|}
\hline No. & $\begin{array}{c}\text { Daerah Pengamatan Yang } \\
\text { Diperbandingkan }\end{array}$ & Persentase Kekerabatan \\
\hline 1 & $1-2$ & $47,3 \%$ \\
\hline 2 & $1-3$ & $44,7 \%$ \\
\hline 3 & $1-4$ & $72,3 \%$ \\
\hline 4 & $2-3$ & $54,6 \%$ \\
\hline 5 & $2-4$ & $65 \%$ \\
\hline 6 & $3-4$ & $52,2 \%$ \\
\hline
\end{tabular}

Selanjutnya, hasil yang diperoleh berupa persentase itu digunakan untuk menentukan hubungan antardaerah pengamatan sesuai dengan kriteria sebagai berikut:

Daerah pengamatan $1-2$ adalah dianggap perbedaan subdialek

Daerah pengamatan 1 - 3 adalah dianggap perbedaan subdialek

Daerah pengamatan 1 - 4 adalah dianggap perbedaan dialek

Daerah pengamatan 2 - 3 adalah dianggap perbedaan dialek

Daerah pengamatan $2-4$ adalah dianggap perbedaan dialek

Daerah pengamatan 3 - 4 adalah dianggap perbedaan dialek

Dengan berpijak pada batasan-batasan yang dikemukakan oleh Mahsun (1995) mengenai metode penentuan dialek/subdialek di atas, dapatlah dikatakan bahwa BBL memiliki dua dialek, yaitu:

1. dialek Bugis Haji Lombok Keruak (DBHLK), yang mencakup daerah pengamatan: 1,2 dan 3;

2. dialek Bugis Pelangan khusus daerah pengamatan 4 . 
Penentuan dialek-dialek diatas itu didasarkan pada persentase yang dihasilkan melalui analisis dialektometri. Dari perhitungan itu, dapat dilihat bahwa dari 152 buah peta yang diperbandingkan antara daerah pengamatan 1 dan 2 terdapat 72 buah peta yang berbeda di antara keduanya. Ini artinya, hanya terdapat sebanyak $47,3 \%$ saja yang berbeda sehingga kedua daerah pengamatan tersebut dinyatakan beda subdialek. Daerah pengamatan 1 dan 3 terdapat 68 buah peta yang berbeda bila dipersentasekan sekitar 44,7\% saja yang beda sehingga daerah pengamatan tersebut juga dinyatakan sebagai beda subdialek. Untuk daerah pengamatan 2-3 terdapat 83 buah peta. Ini menunjukan daerah pengamatan tersbut mempunyai perbedaan sekitar 54,6\% sehingga daerah pengamatan tersebut dinyatakan sebagai beda dialek. Kedua daerah pengamatan yang merupakan beda subdialek tersebut diatas dapat disatukan menjadi satu dialek. Dengan kata kata lain, daerah pengamatan di atas dapat dimasukkan ke dalam satu bahasa satu dialek karena ditemukannya bukti-bukti kualitatif yang menyatukan sebagai satu bahasa satu dialek. Bukti kualitatif yang dimaksud adalah untuk daerah pengamatan $1-2,1-3$ ataupun $2-3,8$ buah isoglos yang berupa korespondensi vokal, 4 buah isoglos yang berupa korespondensi konsonan, 9 buah isoglos yang berupa variasi vokal, 7 buah isoglos yang berupa variasi konsonan, dan 16 isoglos yang berupa leksikon.

Selanjutnya, daerah pengamatan 1, 2, dan 3 diatas diperbandingkan dengan daerah pengamatan 4, yakni 1 dengan 4,2 dengan 4, dan 3 dengan 4 masing-masing terdapat 110, 180, dan 84 buah peta yang berbeda atau masing-masing sekitar 72,3\%, 65\%, dan 55,2\% yang berbeda yang berarti baik antara daerah pengamatan 1 dengan 4, 2 dengan 4 , dan 3 dengan 4 masing-masing merupakan dialek yang berbeda. 


\subsection{Hubungan Kekerabatan Dialek-Dialek Bahasa Bugis di Pulau Lombok}

Pada bagan di atas telah digambarkan tentang penentuan dialekdialek bahasa bugis di Pulau Lombok. Dari deskripsi itu, didapatkan ada dua buah dialek bahasa Bugis yang ada di Pulau Lombok. Kedua dialek itu mempunyai hubungan kekerabatan. Akan tetapi, hubungan kekerabatan yang dimaksud di sini hanya pada tinggi atau rendahnya kedekatan diantara kedua dialek tersebut. Dari perhitungan dialektometri terlihat bahwa daerah pengamatan 1 dengan 3 mempunyai hubungan lebih dekat dengan persentase $44,7 \%$ dibanding dengan daerah pengamatan 1 dengan 2 terdapat 47,3\% dan daerah pengamatan 2 dengan 3 terdapat 54,6\% dari persentase tersebut dijumlahkan dan dibagi ratarata diperoleh hasil 56\%. Untuk memperkuat perhitungan persentase tersebut dibuktikan dengan bukti kualitatif yang menyatukan daerah pengamatan 1 dengan 3, yaitu 1 buah isoglos yang berupa korespondensi vokal, 1 korespondensi konsonan, 3 buah variasi vokal, 3 buah variasi konsonan dan 7 buah yang berupa leksikon. Untuk daerah pengamatan 4 bila diperbandingkan dengan daerah pengamatan 1,2 dan 3 diperoleh sekitar 72,3\% , 65,7\% dan 55,2\% . Dengan demikian, berarti bahwa daerah pengamatan 4 mempunyai hubungan yang jauh dengan daerah pengamatan 1,2 dan 3 .

Selanjutnya sebagai bukti kualitatif yang menyatukan daerah pengamatan 1 dengan 2 yang terdiri atas 2 buah korespondensi vokal kurang sempurna, 2 buah korespondensi konsonan, 5 variasi vokal, 2 buah variasi konsonan dan 8 buah leksikon. Untuk daerah pengamatan 1 dengan 3 yang terdiri atas 1 buah korespondensi vokal, 1 korespondensi konsonan, 3 buah variasi vokal, 3 buah variasi konsonan, 7 buah leksikon. Untuk daerah pengamatan 1 dengan 4 yang terdiri atas 4 buah 
korespondensi vokal, 1 korespondensi konsonan, 1 buah variasi vokal, 2 variasi konsonan, 1 leksikon. Untuk daerah pengamatan 2 dengan 3 yang terdiri atas 4 korespondensi vokal, 1 buah korspondesi konsonan, 1 buah variasi vokal, 2 buah variasi konsonan, 1buah leksikon. Untuk daerah pengamatan 2 dengan 4 yang terdiri atas 1 buah korespoensi vokal, 1 buah korespondensi konsonan, 3 buah variasi vokal, 3 buah variasi konsonan, 3 leksikon. Untuk daerah pengamatan 3 dengan 4 yang terdiri atas 4 buah korespondensi vokal, 1 buah korespondensi konsonan, 1 buah variasi vokal, 2 buah variasi konsonan, dan 1 buah leksikon.

Seperti yang tergambar pada pohon kekerabatan di bawah ini.

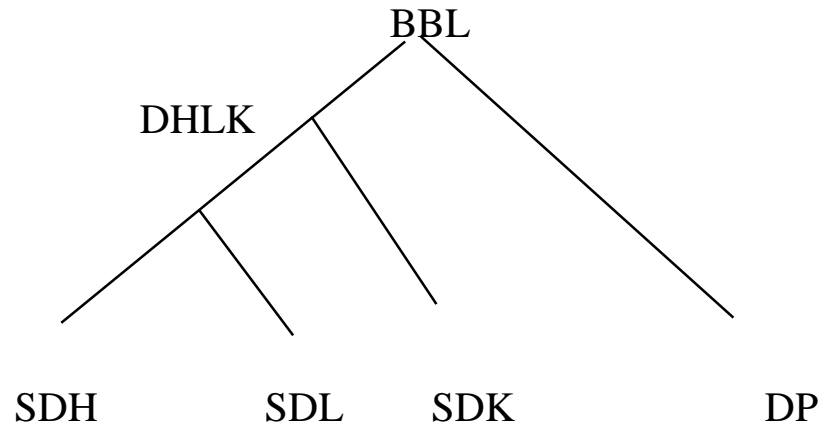

Dari pohon kekerabatan BBL tersebut di atas dapat disimpulkan bahwa migrasi yang pertama pada DBHLK ini terjadi secara besarbesaran. Hal ini dapat dilihat pada dialek ini terdapat dua subdialek yang tersebar pemakaiannya di dua wilayah berbeda subdialek DBHL di Kecamatan Labuhan Haji, subdialek yang kedua DBLK terdapat di wilayah Kecamatan Pringgabaya dan Keruak. Hal ini berbeda dengan yang ada di Sekotong yang hanya berdiri sendiri dan tidak mempunyai subdialek seperti pada DBLK yang merupakan fase persebaran orang Bugis ke Lombok bagian yang kedua. 

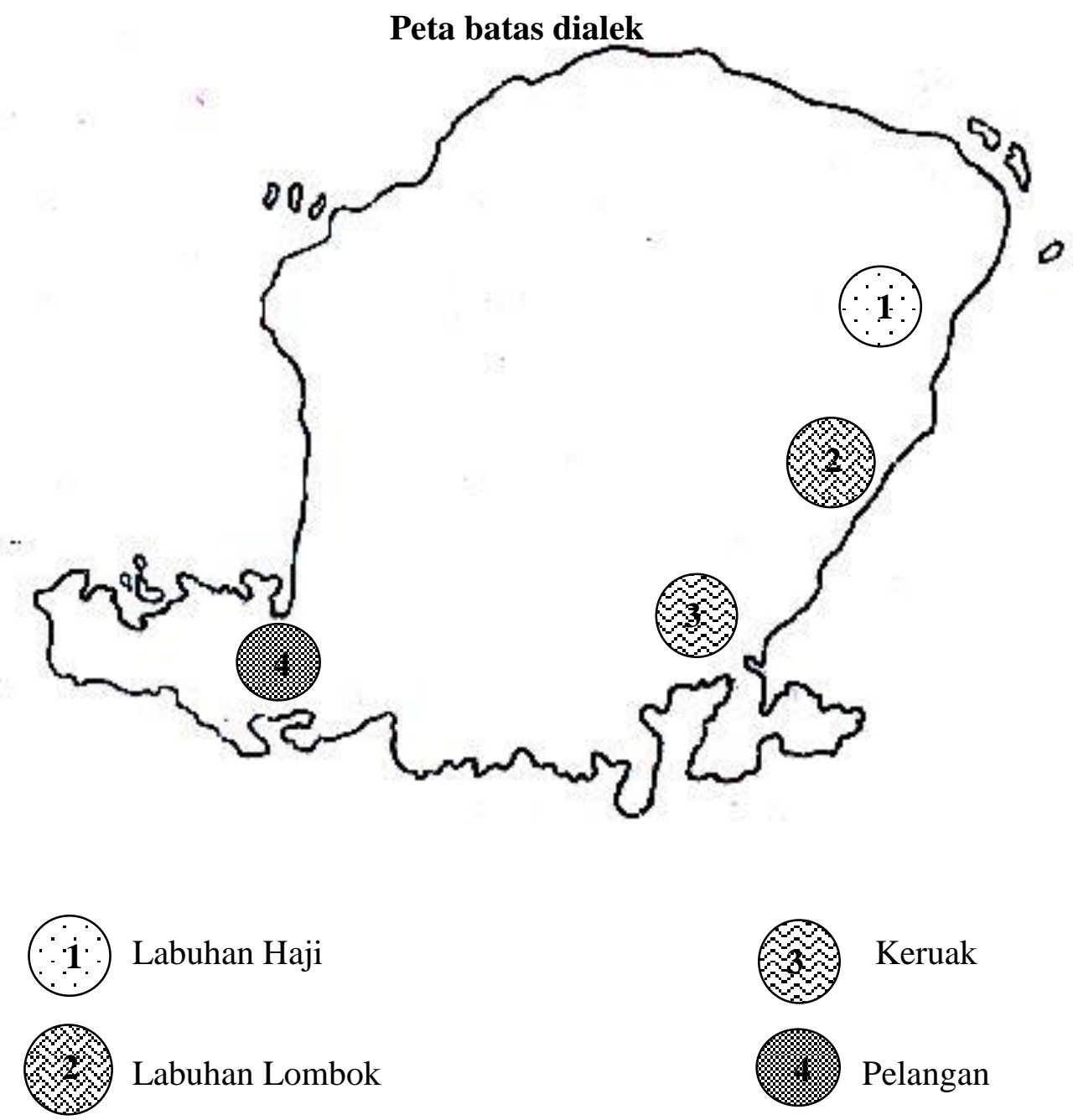

\section{Simpulan}

Dari penelitian yang dilakukan terhadap BBL di Pulau Lombok, dengan menggunakan pendekatan dialektologis, telah diperoleh 152 buah peta perbedaan unsur kebahasaan (fonologi dan leksikon), yang dikumpulkan pada 4 buah daerah pengamatan. Pembahasan terhadap 154 buah peta tersebut dilakukan secara sinkronis dan diakronis, yang hasil pembahasannya dapat dikemukakan sebagai kesimpulan berikut ini. 
Secara sinkronis, pengelompokan daerah-daerah pengamatan yang bertetangga ke dalam daerah dialek atau subdialek didasarkan pada analisis dialektometri. Berdasarkan analisis tersebut terungkap bahwa BBL di Pulau Lombok terbagi ke dalam dua dialek, yaitu DBHLK dan DBP. DBHLK penuturnya sebagian besar menyebar di Desa Labuhan Haji Kecamatan Labuhan Haji, Desa Labuhan Lombok, Kecamatan Pringgabaya, dan Desa Pelangan Kecamatan Sekotong Barat.

Secara diakronis, tingkat kedekatan antara dialek-dialek BBL memiliki perbedaan satu sama lain. DBHLK jauh hubungannya dengan DBP. Dengan demikian dapat dikatakan bahwa pada fase historis penyebaran DBHLK lebih dahulu dari pada DBP. 


\section{DAFTAR PUSTAKA}

Ayatrohaedi. 2002. Penelitian Dialektolgi. Jakarta: Pusat BahasaBynon, T. 1979. Historical Linguisticts: University Press

Bawa, I wayan. 1983. "Bahasa Bali di Bali: Sebuah Analisis Geografi Dialek”.Jakarta: Disertasi pada Program Pascasrjana, Universitas Indonesia

Burhanuddin. 2004."Enklave Samawa di Pulau Lombok Kajian Linguistik Diakronis". Yogyakarta: Tesis pada Program Pascasarjana, Universitas Gajah Mada

Burhanuddin, dkk. 2005."Kontak Bahasa antar Bahasa Sasak dengan Samawa di Lombok Timur. Nusa Tenggara Barat": Kantor Bahasa Provinsi Nusa Tenggara Barat (Laporan Penelitian Kelompok)

Crowley, Terry. 1987. An Introduction Historical Linguistics. Papua New Guinea: University of Papua New Guinea Press

Dyen, Isidore. 1971. The Austronesian Languages and Proto Austonesian Current Trends in Linguistics 8:5-54

Dyen, Isidore, 1978. The position of Languages of Eastern Indonesia. Proceedings SICAL. Fascicle 1: 235 - 254. Pacific Linguiatis. C. 61

Esser,S.J.1938. Atlas van Tropisch Nederland. Batavia Centrum

Herusantoso, Suparman dkk. 1987. Pemetaan Bahasa-Bahasa di Nusa Tenggara Barat Jakarta: Pusat Pembinaan dan pengembangan Bahasa

Haas, Mary. 1966. The Prehiatory of Languages. The Hague: Mouton

Kridalaksana, Harimurti. 1984. Kamus linguistik. Jakarta: PT Gramedia

Lehman, Win fred. 1973. Historical Linguistics: An Introduction. New York: Holt, Rinehart, and winston Inc. 
Lauder, Multamia, R.M.T. 1998. "Usaha Melacak Bahasa-bahasa Nusantara". Makalah Pertemuan Linguistik Bahasa dan Budaya Atmajaya (PELBBA 2).

. 1990. "Pemetaan dan Distribusi Bahasabahasa di Tangerang" Jakarta: Disertasi pada program Pascasarjana, Universitas Indonesia.

Mahsun. 1994. Penelitian Dialek Geografis Bahasa Sumbawa. Yogyakarta: Universitas, University Press . 1995. Dialektologi Diakronis: Sebuah Pengantar. Yogyakarta: Universitas Gajah Mada (Disertasi Doktor)

. 1997. "Linguistik Diakronis dan Pengembangan Materi Muatan Lokal Bahasa Daerah yang Berwawasan Kebangsaan”. Makalah Pada Seminar Internasional Bahasa Dan Budaya di Dunia Melayu, Universitas Mataram, Juli 1997.

Sudika, I Nyoman dkk. 2004. "Bahasa Samawa dan Bahasa Bali di Pulau Lombok”. Nusa Tenggara Barat: KAntor Bahasa Provinsi Nusa Tenggara BArat (Laporan Penelitian Kelompok)

Teuw,A.1951. Dialect-Atlas van of Lombok. Jakarta: Biro Reproduksi Djawatan Tofografi.

Wurm, S.A. and S. Hattori. 1983. "Map of Insular Southeast Asia II". Pacifics Linguistics. C.76 